\title{
Renewable Energy Penetration in Warri Metropolis
}

\author{
Oyeleke Oluwaseun Oyerinde
}

\section{ABSTRACT}

Energy plays an important role in the economic growth, development and security of any nation. Despite having abundant supply of both renewable and nonrenewable energy resources, Nigeria still experiences acute shortage of energy supply to its populace. Currently, the country depends largely on its fossil fuels derived from the Niger Delta region with attendant negative environmental impacts in the area. It is advocated that a switch to renewable sources will eradicate or at least ameliorate some of the environmental challenges. This study attempts to gauge the feasibility and potential of renewable energy (RE) to become a substitute or at the minimum a significant complement to fossil fuels in Nigeria with focus on Niger Delta. As such, attempt is made to assess the current degree of penetration of RE by measuring the level of awareness and utilization as well as identifying factors affecting utilization in the region using Warri metropolis as a case study. 232 survey questionnaires was deployed in the four local government areas - Okpe, Udu, Uvwie and Ughelli-North - that makes up the metropolis across households, commercial ventures and industries with 180 retrieved. Results show that awareness is highest among households at $66 \%$ and lowest for commercial ventures and industry at $30 \%$. Utilization was generally low at $23 \%$ across households while none of the commercial ventures and industries sampled utilizes RE with most citing cost of installation and maintenance viz a viz their power requirement as a major factor. ANOVA shows there is no significant difference in behavior across locations while chi square test affirms that RE utilization is a function of awareness. Outcome points to need for greater awareness campaign and cost reduction of RE technologies.

Keywords: Energy Awareness, Energy Penetration, Energy Utilization, Niger Delta, Renewable Energy.

Published Online: March 30, 2021

ISSN: 2684-446X

DOI : 10.24018/ejgeo.2021.2.2.122

Oyeleke Oluwaseun Oyerinde*

Department of Environmental Management and Toxicology, Federal University of Petroleum Resources Effurun, Delta State, Nigeria.

(e-mail: oyerinde.oyeleke ${ }^{\circledR}$ fupre.edu.ng)

*Corresponding Author

\section{INTRODUCTION}

Energy is often defined as the ability to do work. Energy is used to achieve everyday activities such as transportation, cooking, preservation lighting among others. On the basis of availability or renewability, there are two broad classes of energy; non-renewable and renewable energy [1].

Non-renewable energy resources are energy resources that cannot be replenished and cannot be available for future need once they are depleted. They are generally utilized much faster than nature can replenish them mainly because their rate of formation is extremely slow. Examples include solid minerals and fossil fuels. Renewable energy on the other hand is naturally replenished on a human timescale. These include sunlight, wind, rain, tides, waves, and geothermal heat [2].

For the purpose of this study, penetration refers to the degree or extent of utilization of particular renewable energy by energy consumers within a defined area at a specific period. It includes percentage relative to the total amount of users and the quantity utilized by the consumers. That is, the amount of the utilization of energy generated from renewable resource like sun, wind, water among others.

Over the years, Nigeria, Niger Delta region inclusive, has experienced and suffered different issues of insufficient energy which has impacted the inhabitants negatively. This is because energy plays a crucial role in the lives of the people. Ceaseless flow energy supply is paramount for all nations today. Future economic growth and development depends on long-term availability of energy from sources that are affordable, accessible, and environmentally friendly [3].

The energy crunch, which has overwhelmed Nigeria for a long time is dire and has largely contributed to the incidence of poverty by grounding numerous industrial and commercial activities. Aside the huge income loss and prevalent unemployment from destruction of farmlands, pollution of water sources, and disruption of other ecosystem services from oil spills, it has also resulted in health hazards due to the exposure to carbon emissions from gas flares in the Niger Delta worsened by persistent use of generators in different households and business enterprises.

$\mathrm{RE}$ is considered to be environmentally friendly because they are not burned unlike the fossil fuels, they do not release pollutants into the atmosphere. Hence, they provide a cleaner and healthier environment. Studies have shown that the Niger Delta is endowed in renewable energy sources, which can be exploited to solve all energy related problems facing the Niger Delta region [4]-[6]. Most studies on renewable energy in Nigeria focuses on potentials of various RE resources and forms from supply side usually at macro level [7]-[10]. There is paucity of surveys conducted at micro level focusing on consumer or end-user side.

In view of these, it is therefore the focus of this study to 
ascertain the level of renewable energy penetration with a view to assessing its potentials as a solution to the energy challenges identified above in the region. In order to achieve this, the study aims to measure the level of awareness about renewable energy in Warri metropolis, assess the level of renewable energy utilization and identify factors affecting renewable energy utilization in the area.

\section{STUDY AREA}

Delta state lies approximately between $5.53250 \mathrm{~N}$ and 5.89870E. It is bounded in the north and west by Edo State, the east by Anambra, Imo, and Rivers States, southeast by Bayelsa State, and on the southern flank is the Bight of Benin which covers about 160 kilometers of the 9 state's coastline. Delta State is generally low-lying without remarkable hills.

Delta State is an oil and agricultural producing state in Nigeria. Delta state is situated in the region known as the South-South geo-political zone with a population of $4,112,445$. The capital city is Asaba, located at the northern end of the state, while Warri is the economic nerve center of the state and also the most populated. The state has a total land area of 16,842 square kilometers (6,503 square miles).

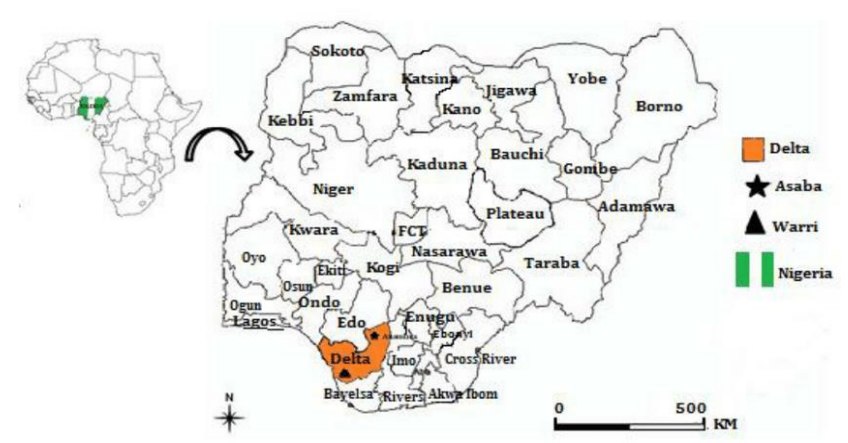

Fig. 1. Map of Nigeria showing Delta State [10].

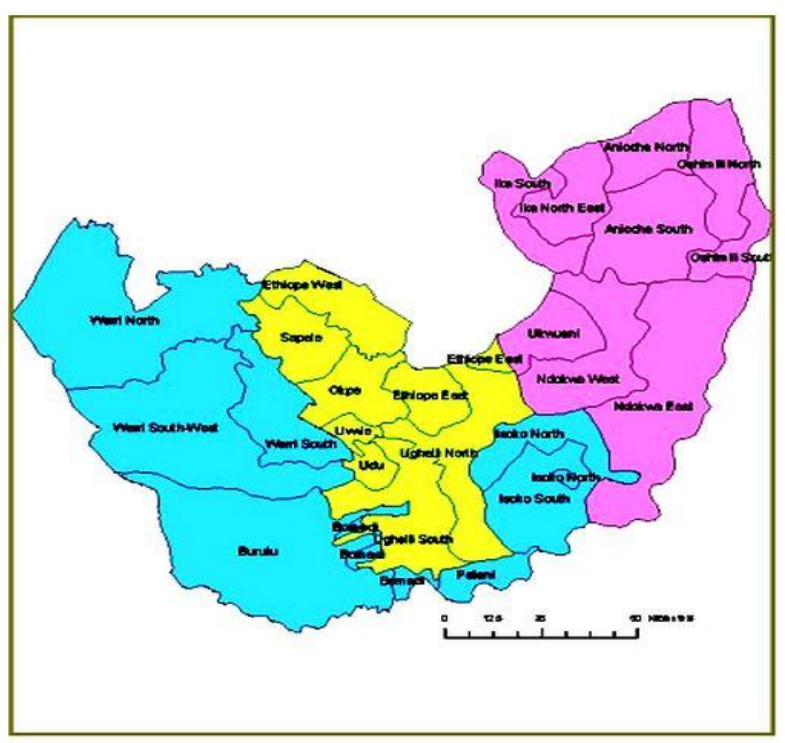

Fig. 2. Map of Delta State showing the Study Area.

Warri Metropolis which comprises of Ughelli north, Udu, Uvwie and Okpe Local Government Areas is one of the most important and busiest cities in Delta state. Warri Metropolis is located between $5.55440 \mathrm{~N}$ and $5.79320 \mathrm{E}$. It is situated 30 to 48 miles upstream from the port of forcados and at the terminus road of Sapele and Ughelli. As a major industrial city of Delta State, on the Niger Delta region it is bounded by Warri North in the northern part of the state, in the west by Warri southwest in the east by Okpe and Ughelli while in the south by Burutu and Ughelli South Local Government Areas. The areas form part of the Warri-Effurun industrial axis in Delta State.

\section{Methodology}

\section{A. Data Collection}

The data for this study was collected using structured questionnaire A total of two hundred and thirty-two (232) questionnaires were administered across the four local government areas that comprises Warri metropolis namely; Udu, Ughelli north, Uvwie, Okpe, local government areas of Delta State. The survey questionnaire was sectioned into household, commercial and industrial sections. The study employs a hierarchical, multi-stage sampling technique.

\section{B. Sampling Framework}

Sample size is derived from sample population using adjusted proportional sampling method.

TABLE I: SAMPLING POPULATION AND SAMPLE SizE

\begin{tabular}{ccccc}
\hline $\begin{array}{c}\text { Local } \\
\text { Government Area }\end{array}$ & $\begin{array}{c}2006 \\
\text { Population } \\
\text { Census }\end{array}$ & $\begin{array}{c}\text { Projected } \\
\text { Population }\end{array}$ & $\begin{array}{c}\text { Estimated } \\
\text { Household }\end{array}$ & $\begin{array}{c}\text { Sample } \\
\text { Size }\end{array}$ \\
\hline Ughelli North & 320,687 & 481,974 & 96,395 & 96 \\
Uvwie & 188,728 & 284,232 & 56,846 & 56 \\
OKpe & 128,398 & 193,372 & 38,674 & 38 \\
Udu & 142,480 & 214,580 & 42,916 & 42 \\
Total & & & 234,832 & 232 \\
\hline
\end{tabular}

Table I shows the 2006 population census of Nigeria [12], in four local governments of Warri and how they are projected using average annual growth rate of $3.2 \%$ [13]. The national average household size used in the table is five (5) [13] and a proportion of 0.001 was used to derive the sample size.

Compounded average annual growth formula:

$$
A=P \times(1+r) \times N
$$

where,

$\mathrm{P}=$ old population;

$\mathrm{r}=$ annual growth rate;

$\mathrm{N}=$ number of years;

$\mathrm{A}=$ new population.

TABLE II: LOCATIONS AND QUESTIONNAIRE DISTRIBUTION

\begin{tabular}{ccccc}
\hline $\begin{array}{c}\text { Local } \\
\text { Government } \\
\text { Area }\end{array}$ & Location & Households & Commercial & Industries \\
\hline \multirow{3}{*}{ Ughelli North } & Ekredjebor & 18 & 9 & 5 \\
& Ekuigbo & 18 & 9 & 5 \\
& Agbarho & 17 & 10 & 5 \\
Uvwie & Iterigbi & 10 & 6 & 3 \\
& Ugbomro & 10 & 6 & 2 \\
& Ekpan & 11 & 5 & 3 \\
Okpe & Ugolo & 7 & 3 & 2 \\
& Orerokpe & 7 & 4 & 2 \\
Udu & Osubi & 7 & 4 & 2 \\
& Oto-kutu & 8 & 4 & 2 \\
Total & Opete & 8 & 4 & 2 \\
\hline
\end{tabular}




\section{Data Analysis}

Data generated was analyzed using descriptive, analysis of variance (ANOVA) to test for significance in pattern and chi square to test for dependence.

\section{Discussion OF RESUlt}

\section{A. Household Socio-Economic Characteristics}

A total of 232 questionnaires were deployed with a total of 180 retrieved, 100 for households and 80 for commerce and industry.

TABLE III: HOUSEHOLD SOCIO-ECONOMIC CHARACTERISTICS

\begin{tabular}{|c|c|c|c|c|}
\hline & Uvwie & Okpe & $\begin{array}{l}\text { Ughelli } \\
\text { North }\end{array}$ & Udu \\
\hline \multicolumn{5}{|l|}{ Gender } \\
\hline Male & $\mathbf{1 8}(64.3 \%)$ & $\mathbf{1 6}(76.2 \%)$ & $\mathbf{1 9}(63.3 \%)$ & $\mathbf{9}(42.9 \%)$ \\
\hline Female & $10(35.7 \%)$ & $\mathbf{5}(23.8 \%)$ & $\mathbf{1 1}(36.7 \%)$ & $\mathbf{1 2}(57.1 \%)$ \\
\hline \multicolumn{5}{|l|}{ Age Group } \\
\hline $18-25$ years & $2(7.1 \%)$ & $\mathbf{5}(23.8 \%)$ & $7(23.3 \%)$ & $\mathbf{8}(38.1 \%)$ \\
\hline 26-30 years & $\mathbf{1 3}(46.4 \%)$ & $\mathbf{9}(42.9 \%)$ & $\mathbf{9}(30 \%)$ & $\mathbf{8}(38.1 \%)$ \\
\hline $31-40$ years & $\mathbf{1 3}(46.4 \%)$ & $7(33.3 \%)$ & $8(26.7 \%)$ & $\mathbf{5}(23.8 \%)$ \\
\hline 41 years $\&$ above & & & $\mathbf{6}(20 \%)$ & \\
\hline \multicolumn{5}{|l|}{ Education } \\
\hline Primary Education & $\mathbf{1}(3.6 \%)$ & & & $\mathbf{1}(4.8 \%)$ \\
\hline Secondary Education & $\mathbf{1 1}(39.3 \%)$ & $\mathbf{9}(42.9 \%)$ & $2(6.7 \%)$ & $7(33.3 \%)$ \\
\hline Higher Education & $\mathbf{1 6}(57.1 \%)$ & $\mathbf{1 1}(52.4 \%)$ & $\begin{array}{c}9(30 \%) \\
19(633 \%)\end{array}$ & $\mathbf{1 1}(52.4 \%)$ \\
\hline Others & & $\mathbf{1}(4.8 \%)$ & & $2(9.5 \%)$ \\
\hline \multicolumn{5}{|l|}{ Occupation } \\
\hline Civil Servant & $\mathbf{5}(17.9 \%)$ & $\mathbf{3}(14.3 \%)$ & $2(6.7 \%)$ & $2(9.5 \%)$ \\
\hline Self Employed & $\mathbf{1 5}(53.6 \%)$ & $13(61.9 \%)$ & $21(70 \%)$ & $\mathbf{1 4}(66.7 \%)$ \\
\hline Traders & $\mathbf{3}(10.7 \%)$ & $\mathbf{2}(9.5 \%)$ & $\mathbf{4}(13.3 \%)$ & $\mathbf{5}(23.8 \%)$ \\
\hline Unemployed & $\mathbf{5}(17.9 \%)$ & 2(9.5\%) & $\mathbf{3}(10 \%)$ & \\
\hline $\begin{array}{l}\text { Others } \\
\text { Total }\end{array}$ & 28 & 21 & 30 & 21 \\
\hline
\end{tabular}

From Table III, more males were encountered in all the four LGAs except Udu LGA. The highest age group recorded among the four LGAs is 2630 years, while the least age group was found to be from 41 years and above. Table III further indicates that the highest level of education attained across the four LGAs is Higher education. The occupational status of the respondents from all LGAs showed Self-employed as the highest, followed by trading. with the least form of occupation to be Unemployed across the four locations.

B. Renewable Energy Awareness

\begin{tabular}{ccccc}
\multicolumn{5}{c}{ TABLE IV: RENEWABLE ENERGY AWARENESS IN HOUSEHOLDS } \\
\hline & Uvwie & Okpe & $\begin{array}{c}\text { Ughelli } \\
\text { North }\end{array}$ & Udu \\
\hline Awareness & & & & \\
Yes & $\mathbf{1 8}(63.3 \%)$ & $\mathbf{1 6}(76.2 \%)$ & $\mathbf{2 2}(73.3 \%)$ & $\mathbf{1 0}(47.6 \%)$ \\
No & $\mathbf{1 0}(35.7 \%)$ & $\mathbf{5}(23.8 \%)$ & $\mathbf{8}(26.7 \%)$ & $\mathbf{1 1}(52.4 \%)$ \\
Source & & & & \\
Media & $\mathbf{1 4}(50 \%)$ & $\mathbf{1 4}(66.7 \%)$ & $\mathbf{2 1}(70 \%)$ & $\mathbf{9}(42.9 \%)$ \\
NGO & $\mathbf{3}(10.7 \%)$ & $\mathbf{3}(14.3 \%)$ & $\mathbf{0}$ & $\mathbf{1}(4.8 \%)$ \\
Others & $\mathbf{1}(3.6 \%)$ & $\mathbf{1}(4.8 \%)$ & $\mathbf{2}(6.7 \%)$ & $\mathbf{0}$ \\
None & $\mathbf{1 0}(35.7 \%)$ & $\mathbf{3}(14.3 \%)$ & $\mathbf{7}(23.3 \%)$ & $\mathbf{1 1}(23.3 \%)$ \\
Total & $\mathbf{2 8}$ & $\mathbf{2 1}$ & $\mathbf{3 0}$ & $\mathbf{2 1}$ \\
\hline
\end{tabular}

Table IV shows that $66 \%$ of the entire population in the study area are aware of RE with highest being $76 \%$ at Okpe and least at Udu with $47.6 \%$. Source reveals that the media is the most influential source of information on renewable energy. Other sources include NGOs and worship centers.

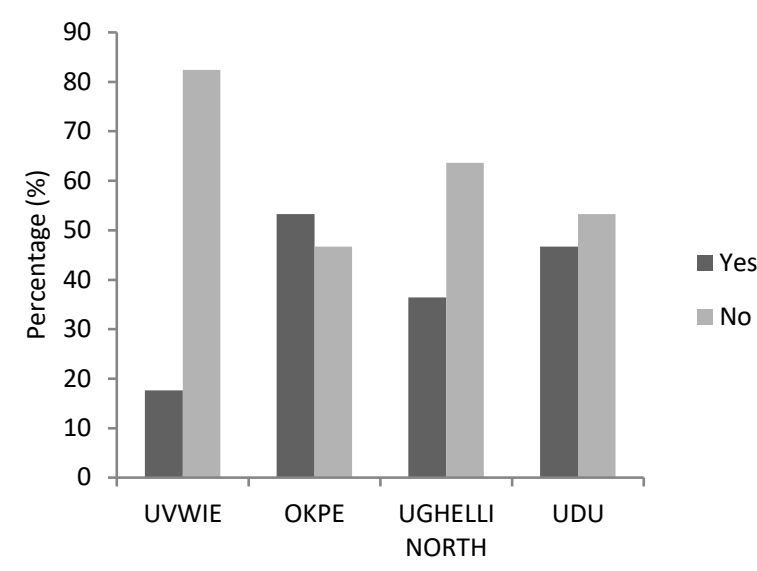

Fig 3. Renewable Energy Awareness in Commercial Ventures and Industries.

Fig. 3 shows that awareness is generally low among commercial and industrial operators, at $30 \%$, compared to households $(66 \%)$. It is highest at Okpe and least in Uvwie.

Test for Variation in the Level of Renewable Energy Awareness among Locations and Attributes of the Four LGAs.

TABLE V: ANOVA TEST FOR VARIATION IN RENEWABLE ENERGY

\begin{tabular}{cccccc}
\multicolumn{7}{c}{ AwARENESS ACROSS HousEHOLDS } \\
\hline \multirow{2}{*}{ Households } & Mean & Std Dev. & F & Df & P-Value \\
\hline Uvwie & 2.04 & .838 & 2.648 & 27 & .116 \\
Okpe & 2.00 & .837 & 1.541 & 20 & .230 \\
Ughelli -North & 2.00 & .830 & 0.241 & 29 & .628 \\
Udu & 2.00 & .837 & 0.263 & 20 & .614 \\
\hline
\end{tabular}

Significant at 0.05 level.

The ANOVA result presented in Table VI shows that there is no significant difference between the location's household attributes.

TABLE VI: TEST FOR VARIATION IN RENEWABLE ENERGY AWARENESS ACROSS COMMERCIAL VENTURES/INDUSTRIES

\begin{tabular}{cccccc}
\hline \multirow{2}{*}{ Commercial/Industry } & \multicolumn{5}{c}{ Awareness } \\
\cline { 2 - 6 } & Mean & Std Dev. & F & df & P-value \\
\hline UVWIE & 3.24 & 1.751 & 0.210 & 16 & .653 \\
OKPE & 3.40 & 1.765 & 0.873 & 14 & .367 \\
UGHELLI -NORTH & 3.15 & 1.679 & 1.257 & 32 & .271 \\
UDU & 3.40 & 1.765 & 0.116 & 14 & .739 \\
\hline
\end{tabular}

Significant at 0.05 level.

The ANOVA result presented in Table VI shows that there is no significant difference in level of renewable energy awareness across the Four LGAs commercial ventures/industries.

\section{Renewable Energy Utilization}

Table VII below show that only $23 \%$ of households surveyed make use of RE which is primarily wood across the four LGAs. Expenditure is also demonstrated to be less than N5,000 monthly in all the households. 


\begin{tabular}{lcccc}
\multicolumn{5}{c}{ TABLE VII: RENEWABLE ENERGY UTILIZATION IN HOUSEHOLDS } \\
\hline & Uvwie & Okpe & $\begin{array}{c}\text { Ughelli } \\
\text { North }\end{array}$ & Udu \\
\hline Usage & $\mathbf{9}(32.1 \%)$ & $\mathbf{4}(19 \%)$ & $\mathbf{9}(30 \%)$ & $\mathbf{1}(4.8 \%)$ \\
Yes & $\mathbf{1 9}(67.9 \%)$ & $\mathbf{1 7}(81 \%)$ & $\mathbf{2 1}(70 \%)$ & $\mathbf{2 0}(95.2 \%)$ \\
No & & & & \\
Re Energy Type & $\mathbf{1}(100 \%)$ & $\mathbf{2 ( 1 0 0 \% )}$ & $\mathbf{4}(100 \%)$ & $\mathbf{1}(100 \%)$ \\
Wood & & & \\
Re Expenditure & & $\mathbf{2}$ & \\
Below N4900 & $\mathbf{1}(100 \%)$ & $\mathbf{2 ( 1 0 0 \% )}$ & $\mathbf{4}(100 \%)$ & $\mathbf{1}(100 \%)$ \\
Total & $\mathbf{2 8}$ & $\mathbf{2 1}$ & $\mathbf{3 0}$ & $\mathbf{2 1}$ \\
\hline
\end{tabular}

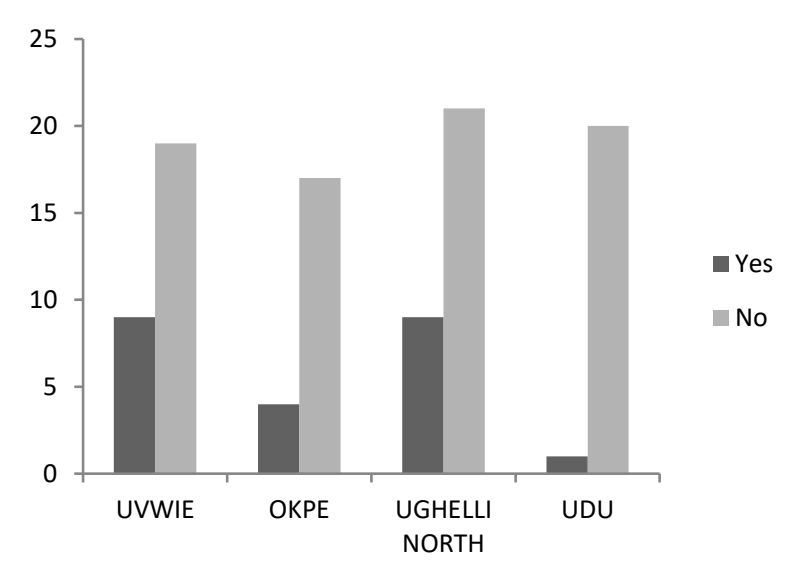

Fig. 4. Household Utilization of Renewable Energy.

TABLE VIII: RENEWABLE ENERGY UTILIZATION OF THE FOUR LGAA FOR COMMERCIAL VENTURE AND INDUSTRIES

\begin{tabular}{|c|c|c|c|c|}
\hline & Uvwie & Okpe & $\begin{array}{l}\text { Ughelli } \\
\text { North }\end{array}$ & Udu \\
\hline \multicolumn{5}{|l|}{ Utilization } \\
\hline Yes & 0 & 0 & 0 & 0 \\
\hline No & $17(100 \%)$ & $15(100 \%)$ & $33(100 \%)$ & $15(100 \%)$ \\
\hline Total & 17 & 15 & 33 & 15 \\
\hline
\end{tabular}

Table VIII indicates that, no commercial venture/ industries across the four locations utilize renewable energy.

Test for Variation in the Utilization of Renewable Energy among Locations and Attributes of the Four LGAs.

TABLE IX: TEST FOR VARIATION IN RENEWABLE ENERGY UTILIZATION ACROSS HOUSEHOLDS

\begin{tabular}{cccccc}
\hline \multicolumn{6}{c}{ ACROSS HOUSEHOLDS } \\
\cline { 2 - 6 } Households & \multicolumn{5}{c}{ Utilization } \\
\cline { 2 - 6 } & Mean & Std Dev. & F & df & P-value \\
\hline Uvwie & 2.04 & .838 & 1.717 & 27 & .202 \\
Okpe & 2.00 & .837 & 0.429 & 20 & .521 \\
Ughelli -North & 2.00 & .830 & 6.931 & 29 & .0 .14 \\
Udu & 2.00 & .837 & 0.000 & 20 & 1.000 \\
\hline
\end{tabular}

Significant at 0.05 level.

The ANOVA result presented in Table IX indicates that there is no significant difference in the utilization among Uvwie, Okpe and Udu. However significant difference exists between the attributes in Ughelli-North as a result of the uneven distribution in Ekredjebor attribute.

\section{Relationship between Awareness and Utilization}

TABLE X: TEST FOR DEPENDENCE BETWEEN AWARENESS AND UTILIZATION OF RENEWABLE ENERGY ACROSS HOUSEHOLDS IN THE FOUR

\begin{tabular}{|c|c|c|c|}
\hline \multicolumn{4}{|c|}{ LGAS } \\
\hline & $\mathrm{X}^{2}$ & $\mathrm{df}$ & Sig. \\
\hline Uvwie & 7.368 & 1 & .007 \\
\hline Okpe & 1.544 & 1 & .241 \\
\hline Ughelli-North & 4.675 & 1 & .031 \\
\hline Udu & 1.155 & 1 & .283 \\
\hline
\end{tabular}

Significant at 0.05 level.
From Table $\mathrm{X}$, significant difference exists within the household LGA of Uvwie and Ughelli-North. This further tells us that the utilization of renewable energy the two LGAs is independent of their level of awareness. Okpe and Udu LGA shows there is no significant difference between their level of awareness and utilization. Thus, utilization of renewable energy is dependent on the awareness of renewable energy by Okpe and Udu LGA.

\section{CONCLUSION}

The level of awareness in the commercial and industrial sectors is very low as they have little or no idea about RE. Households that are aware of RE technologies hardly utilize, they rely mainly on the non- renewable forms of energy to cope with their daily energy needs. The generally low awareness and extremely low utilization levels point to minimal penetration of renewable energy in the study area. This is partly due to low level of sensitization on renewable energy to the public and cost of installation and maintenance. Clearly, a lot need to be done in terms of increasing RE awareness through aggressive publicity campaigns and stimulating utilization via attractive incentives for it to become a viable alternative or complement to fossil fuels in Niger Delta in the near future.

\section{REFERENCES}

[1] A. Helmenstine (2018). Energy Definitions and Examples (Science). https//:sciencenotes.org/energy-definitions-examples/ Accessed 5th February 2021.

[2] O. Ellaban, H. Abu-Rub and B. Frede (2014). "Renewable Energy Resources: Current Status, Future Prospects and their Enabling Technology". Renewable and Sustainable Energy Reviews, Vol. 39, 748-764.

https://www.academia.edu/10612104/Renewable_energy_resources_ Current_status_future_prospects_and_their_enabling_technology.

[3] E.O. Diemuodeke and T.A. Briggs (2018). "Policy Pathways for Renewable and Sustainable Energy Utilisation in Rural Coastline Communities in the Niger Delta Zone of Nigeria”. Energy Reports Vol. 4, 638-644.

https://www.sciencedirect.com/science/article/pii/S235248471830092 1.

[4] E.O. Diemuodeke, I. Addo, C.O.C., Oko, and Y. Mulugetta (2017). "Domestic Energy Demand Assessment of Coastline Rural Communities with Solar Electrification”. Energy Policy Research. 4 (1), 1-9.

https://www.tandfonline.com/doi/full/10.1080/23815639.2017.12804 31

[5] C.O. Nwokocha, U.K. Okoro, and C.I. Usoh (2018). "Photovoltaics in Nigeria Awareness, Attitude and expected Benefit based on a Qualitative Survey across Regions". Renewable Energy, Elsevier, 116, 176-182. https://ideas.repec.org/a/eee/renene/v116y2018ipap176182.html.

[6] C.O. Okoye, O.B. Taylan, and K. Derek (2016). "Solar Energy Potentials in Strategically located Cities in Nigeria: Review, Resource Assessment and PV System Design". Renewable and Sustainable Energy Review. 55, 550-566.

https://www.sciencedirect.com/science/article/abs/pii/S136403211501 2332

[7] J.F.K. Akinbami, M.O. Ilori, T.O. Oyebisi, I.O. Akinwunmi, and O. Adeoti (2001). "Biogas Energy Use in Nigeria: Current Status, Future Prospects and Policy Implications". Renewable and Sustainable Energy Review, (5)1, 97-112.

https://www.sciencedirect.com/science/article/abs/pii/S136403210000 0058

[8] S.O. Oyedepo, T. Uwoghiren, P.O. Babalola, S.C. Nwanya, O. Kilanko, R.O. Leramo, A.K. Aworinde, T. Adekeye, J.A. Oyebanji and O.A. Abidakun (2019). "Assessment of Decentralized Electricity Production from Hybrid Renewable Energy Sources for Sustainable Energy Development in Nigeria”. De Gruyter, Open Eng, 9, 72-89. 
https://www.degruyter.com/document/doi/10.1515/eng-2019-

$0009 / \mathrm{html}$

[9] C.C. Uzoma, C.E. Nnaji, C.N. Ibeto, C.G. Okpara, O.O. Nwoke, I.O. Obi, G.O. Unachukwu, and O.U. Oparaku (2011). "Renewable Energy Penetration in Nigeria: A Study of the South-East Zone". Continental J. Environmental Sciences 5 (1), 1-5. https://www.researchgate.net/publication/215909831_Renewable_ene rgy_penetration_in_Nigeria_A_study_of_the_South-East_Zone.

[10] S.I. Sofimieari and M.W. Mustafa (2018). "Evaluation of Renewable Energy Resources Potential for Satisfying Electricity Needs in the Niger Delta Region". ARPN Journal of Engineering and Applied Sciences. (13)12, 3907 - 3913.

https://www.researchgate.net/publication/326320091_Evaluation_of_r enewable_energy_resources_potential_for_satisfying_electricity_need s_in_the_Niger_Delta_Region.

[11] S. Kundu, T. Mattew, I.S. Janet and A. Ternege (2015). "Retrospective study of Disease Incidence and Other Clinical Conditions Diagnosed Owned Dogs in Delta State, Nigeria". Journal of Advanced Veterinary and Animal Research, 2, 435-449.

https://www.researchgate.net/publication/307718358_Retrospective_s tudy_of_disease_incidence_and_other_clinical_conditions_diagnosed _in_owned_dogs_in_Delta_State_Nigeria.

[12] National Population Commission (NPC) (2006). Nigeria National Census: Population Distribution by Sex, State, LGAs and Senatorial District: 2006 Census Priority Tables Vol. 3.

http://www.population.gov.ng/index.php/publications/140-populationdistribution-by-sex-state-lgas-and-senatorial-district-2006-censuspriority-tables-vol-3.

[13] National Population Commission (2018). National Demographic and Health Survey (NDHS).

https://drive.google.com/file/d/1Y9dm9Mhr1KjLj9asOYuXkutGIxW 8wY06/view. 